\title{
ANALYZING THE IMPACT OF INTEREST RATE ON DRY BULK FREIGHT MARKET WITH TIME-VARYING CAUSALITY METHOD
}

\author{
Faiz Oranının Kuru Dökme Yük Navlun Piyasasına Etkisinin Zamanla Değişen \\ Nedensellik Yöntemiyle Analizi
}

\author{
Abdullah AÇIK*, Özhan OKUTUCU**, \\ Kamil Özden EFES ${ }^{* * *}$ \& Sadık Özlen BAŞER ${ }^{* * * *}$
}

\section{Anahtar \\ Kelimeler: Faiz \\ Oran1, Navlun \\ Piyasas1, Kuru \\ Dökme Yük \\ Taşımacılığı, \\ Nedensellik \\ Analizi.}

JEL Kodları: C58, E43, R41

\begin{abstract}
Keywords: Interest Rate, Freight Market, Dry Bulk Shipping, Causality Analysis.

JEL Codes: C58, E43, R41

The interest rates significantly affect maritime markets, both with their role in determining the cost of ship investments and their role in determining the demand for goods in the world economy. We examined the impact on the freight market, which is the fundamental of other maritime markets and is much more dynamic than them. Considering that change in interest rates affects the world economy, but this effect may not survive throughout the period, we applied the analysis first with a linear approach and then with a time-varying approach. The federal funds rate is used as an indicator of global interest rates, and the Baltic Dry Index (BDI) is used as an indicator of the dry bulk freight market. As a result of analysis performed using a data set consisting of 302 monthly observations covering the period between 1995 and 2020, it was determined that the significant relationship does not exist throughout the whole sample, it exists only at certain periods, and the significant effect occurs when BDI tends to increase and decrease. Thus, it was determined that changes in interest rates not only affect the global economy but also the trend of the dry bulk freight market.
\end{abstract}

\section{Öz}

Faiz oranları hem gemi yatırımlarındaki maliyeti belirleyici rolü hem de dünya ekonomisindeki mallara olan talebi belirleyici rolü ile denizcilik piyasalarını da önemli ölçüde etkilemektedir. Biz bu çalışmamızda diğer denizcilik piyasalarının temeli olan ve onlara göre çok daha dinamik yapıda olan navlun piyasasına olan etkisini incelemeyi amaçladık. Faiz oranlarındaki değişimin dünya ekonomisini etkileyeceğini ancak bu etkinin tüm dönem boyunca varlığını sürdüremeyeceğinden yola çıkarak, önce doğrusal bir yaklaşımla, daha sonra ise zamana göre değişen bir yaklaşımla analizleri uyguladık. Analizlerde küresel faiz oranlarının göstergesi olarak Federal Fon Oranı, kuru dökme yük navlunlarının göstergesi olarak ise Baltık Kuru Yük Endeksi (BKYE) kullanılmıştır. 1995 ve 2020 yılları arasını kapsayan aylık 302 gözlemden oluşan veri seti kullanılarak zamana göre değişen yaklaşım ile yapılan analizler sonucunda, anlamlı ilişkinin tüm örneklem boyunca var olmadığı, sadece belli zamanlarda görüldüğü ve anlamlı ilişkinin görüldüğü dönemlerin BKYE'nin artış ve düşüş eğilimine girdiği dönemler olduğu tespit edilmiştir. Böylece faiz oranlarındaki değişimlerin yalnızca küresel ekonomiyi etkilemekle kalmayıp, kuru dökme yük navlun piyasasının eğilimini de etkilediği belirlenmiştir.

\footnotetext{
* Res. Asst. Dr., Dokuz Eylül University, Maritime Faculty, abdullah.acik@deu.edu.tr, ORCID: 00000003- 4542-9831 (Corresponding author)

** Student, Dokuz Eylül University, Maritime Faculty, okutucuozhan@gmail.com, ORCID: 0000-00030880-5383

*** Asst. Prof. Dr., Piri Reis University, Maritime Faculty, koefes@pirireis.edu.tr, ORCID: 0000-00017087-5337

***** Prof. Dr., Dokuz Eylül University, Maritime Faculty, ozlen.baser@deu.edu.tr, ORCID: 0000-00016632-2617
}

Makale Geliş Tarihi (Received Date): 21.09.2020 ～Makale Kabul Tarihi (Accepted Date): 13.06.2021 


\section{Introduction}

The interest rate is set by the borrower as the price paid to a lender (creditor) for the use of resources, which is the cost of money in short (Fabozzi, Modigliani and Jones, 2014, p. 196). The interest rate is vital to economic activities and is used as a tool by policy-makers to achieve sustainable economic growth. If there are high interest rates in economies, personal and business loan costs increase and fewer people and businesses borrow. This high interest rate reduces demand in the market and slows down economic growth. High interest rates reduce supply by reducing existing capital to expand businesses. Individuals and businesses prefer interest earning rather than investing their savings. As a result, the decrease in liquidity in the market slows the economy. Alternatively, low interest rates have the opposite effect on economies. Saving rates of individuals and businesses decrease. Savers can choose to make more profitable investments when interest earnings decrease. Money shifts to riskier but more profitable investments. Since lower interest rates make loans more affordable, individuals and businesses can get cheaper loans. This process both increases consumption and enables businesses to invest (Agarwal, 2010, p. 115).

Interest rates have a big impact on businesses, especially for the maritime market that holds 80 percent of world transportation (United Nations Conference on Trade and Development [UNCTAD], 2018, p. 4). In addition to the fluctuations in bunker prices, freight rates, newbuilding, and secondhand prices in the maritime market, unforeseen interest rate changes play an important role by affecting both investing preferences of business enterprises and consumption preferences of households. It can be said that this effect does not occur instantly and take effect after a certain period. However, interest rates have a perceptual effect as well as their real effect. Agents in the market make prudential inferences and take positions based on the current interest rate decisions.

Therefore, interest rate decisions have a rapid impact on the world economy. Since maritime transport has a derived demand structure (Vermeulen, 2010, p. 856) that is directly affected by the world economy, the impact of interest rates can be instantly felt. However, this effect may vary depending on the type of maritime market. Maritime transport consists of different markets according to the types of cargo carried, such as dry cargo, liquid cargo, gas, container, general cargo (Branch, 2007, p. 20). The market where the effect of the interest rate is expected to be seen rapidly is dry bulk cargo transportation. The reason for this expectation can be explained by two factors; cargo types and market structure. First, since the cargoes carried in this market consist of raw materials such as iron ore, coal, wheat used in the production of final products (Geman, 2009, p. 191; United Nations [UN], 2009, p. 35), decisions made for production levels can directly reflect on the freight traffic in this market, and the freight level in the market is seen as a good indicator of future economic activity (Langdana, 2009, p. 94; Lawson, 2008, p. 2; Şahin, Gürgen, Ünver and Altin, 2018). Second, the dry bulk market has a structure close to a perfect competitive market (Ma, 2020, p. 304). Many buyers and sellers exist in the market, entry and exit are relatively easy, and the price is determined by the market. In other maritime markets, these features are limited. Therefore, changes in demand can directly affect freight rates in the dry bulk market. However, since there are many factors affecting both interest and freight rates, it may not be possible to talk about an interaction that exists throughout the entire period. Therefore, in our study, we examined the effect of interest rates on the freight market by using time-varying causality analysis, which enables analysis at the subsample level instead of the whole sample. Thus, we tried to determine whether interest rates had 
a statistical effect on freight rates, if so, in what periods and what the prominent features of these periods were. The lack of such a study in the literature to the best of the authors increases the originality of the research. It is hoped that the findings will support agents in the dry bulk market to follow a more accurate strategy by making it possible to monitor the market conditions.

In the second section of the paper, the literature review is conducted to draw a framework to our research. The method is introduced in the third section and the dataset used in the analysis is investigated in the fourth section. After findings related to the empirical analysis are presented in the fifth section, conclusions are made in the last section.

\section{Literature Review}

Studies examining the effect of interest rates on the maritime market are limited in the literature. When we review the literature about the use of our method in the maritime market, there is a study on the dry bulk freight market conducted by Aç1k and Ayaz (2018). The researchers examined the relationship between freight rates and bunker prices with a timevarying approach. One of the main factors affecting freight is bunker prices, and shipowners propose a transport price above their transport costs since they operate their vessels for profit. The bunker price is effective in determining the base price and changes may be reflected in freight rates. However, since freight rates derive from the balance between supply and demand, cost loses its importance during periods of intense demand, and freight rates can reach much more profitable levels. Accordingly, the relationship between bunker price and freight may not exist during the entire period. The authors determined the periods of this relationship by applying time-varying causality analysis and found that there were significant causalities in the periods when the BDI variable had a downward trend. In another maritime-related study, the effect of the exchange rate on container traffic in Turkish ports was investigated by Açı, Sağlam and Tepe (2019). As a result of the research, it has been determined that there are significant relationships from the exchange rate to the port traffic, especially during periods of depreciation in the local currency.

A review of the maritime studies using the time-varying causality approach showed that significant relationships are found in studies where the relationship is not expected to exist throughout whole the sample. In our study, we turned to this approach since we thought that the effect of interest rates on the freight market cannot exist for the whole sample. The main reason for this is that many external factors affect freight rates such as world gross domestic product (Başer and Açı, 2019), industrial production (Strandenes, 1984), bunker price (Açık and Ayaz, 2018; Poulakidas and Joutz, 2009; Shen and Chou, 2015; Yin, Luo and Fan, 2017), secondhand value (Açık and İnce, 2019), fleet size (Karakitsos and Varnavides, 2014, p. 212), laid-up tonnage (Zannetos, 1966), and climatic, cultural, operational factors (Açık and Başer, 2018). It is almost impossible to include all these factors in a single model. Therefore, based on the shaping power of interest rates in the global economy, we thought that the effect of interest rates on the freight market in some periods could be significant regardless of the effect of the other variables.

In a recent study examining the effect of interest rates on the maritime market, new building and demolition markets from maritime sub-markets are discussed by Açık, Kesiktaş 
and Başer (2020). The researchers aimed to estimate the two markets with two models and examine the effect of interest rates on the number of new ordered ships and the number of demolished ships. While setting up the models, they included the freight rate as the control variable, since the effect of it on both markets is indisputable. The results revealed that the impact of the freight rate on amount of new orders was positive while its impact on the amount of ship demolition negative. On the other hand, the impact of interest rates on both markets was negative. Increasing freight rates are triggering new ship order amounts, as shipowners want to take more advantage of higher revenue opportunities. However, increasing freight rates reduce the amount of ships going for demolition, as even old and obsolescence vessels can maintain profitable commercial operations. When the issue is handled by interest rates, increasing capital costs may decrease the amount of both variables because purchasing a new ship becomes more expensive. A second comment may be related to the expectations of investors. When interest rates rise, capital owners may want to invest their money in investment instruments that bring higher returns, rather than ordering new ships.

Another related study examining the effect of interest and freight rates on ship prices was conducted by Youngjae and Hyunsok (2016). The researchers determined the relationship between ship price and interest as negative, and the relationship between ship price and freight rates as positive. Thus, they demonstrated the dependence of ship value on interest and freight rates with the dynamic Gordon model. They also revealed that the ship price is affected more by freight rates than by interest rates. In parallel with Açı et al. (2020), ship-purchasing costs are increasing due to increasing interest rates. This situation affects the price negatively as the demand for ships decreases. Additionally, rising interest rates make alternative sources of income more attractive than transportation activities. On the other hand, the increase in freight rates increases the demand for ships and may even cause speculative price bubbles.

Before studies that obtained results with econometric analysis, there were also studies modeling the relationships with theoretical equations. Beenstock (1985) modeled ship prices to provide helpful paths for the empirical analysis. According to his model, higher interest rates raise freight rates. However, it lowers the ship prices and fleet size. Its positive effect on freight is related to its effect on the demand for ships. As the cost of capital rises, demand for ships decreases, and ship prices also decrease. Additionally, as the demand for new buildings decreases, the fleet tends to shrink. As a result, the supply side may not be able to react to the developments on the demand side as the carrying capacity cannot increase, which consequently may increase freight rates.

As can be seen, studies examining the relationship between interest rates and maritime markets are limited. In the study, which theoretically defines the effect on the freight rates, the relationship between them was established as positive. However, in today's globalizing world, communication is advanced and different organizations in many parts of the world are specialized in the production of certain products. With the effect of increasing competition, this situation may cause the news or shock in a region to spread in a way that affects the whole world. Thus, the relationships between variables may become far from linearity and continuity. Ignoring this possibility may cause to fail to find the interactions that exist. Considering this framework, we analyzed the effect of interest rates on freight rates with a time-varying approach. In this respect, we expected to make an original contribution to the literature. Determining whether interest rates impact freight rates if any, and when they are can provide important findings to industry stakeholders and policymakers. 


\section{Methodology}

Causality analysis is a widely used method first proposed by Granger (1969). The logic of the analysis is simple; if the past and present values of a variable statistically explain the present and future values of the other variable significantly, the first variable is expressed as the Granger cause of the second variable. In other words, Granger causality has a methodology to test whether the lagged values of the first variable are statistically significant (Balcilar and Ozdemir, 2013b). In this test, as in many other ones, the null hypothesis is expressed as noncausality, and this means that the information in the first variable does not contribute to the prediction of the other variable (Inglesi-Lotz, Balcilar and Gupta, 2014).

The simple linear Granger causality handles the whole sample while performing the analysis and gives a single result. However, the relationship between variables may not exist across the whole sample (Balcilar and Ozdemir, 2013a). In other words, while there is a significant relationship in some periods, this relationship may not exist in other periods. The lack of a significant relationship at every point of the sample does not mean that there is no relationship (Balcilar and Ozdemir, 2013b). The main reason may be that the distortion of the linear structures of variables in today's globalizing world, as information spreads very quickly and agents in the market position themselves according to new information (Bildirici and Turkmen, 2015). This situation may result in the structure of the variables becoming nonlinear (Bampinas and Panagiotidis, 2015). Since it is not possible to model all information-containing variables, periods with significant relationships can be identified with a time-varying approach. Additionally, when the analysis is performed based on the whole sample, the structural changes and breaks in the variables may make it difficult to detect significant statistical relationships. Therefore, it may be more useful to apply sectional analysis instead of the whole sample. The bootstrap rolling-window approach is such an application and makes it possible to identify relationships in different periods over time based on sub-samples (Li, Balcilar, Gupta and Chang, 2016). Additionally, we tested the linearity in the models with the Broock, Dechert, and Scheinkman (BDS) Independence Test (Broock, Scheinkman, Dechert and LeBaron, 1987) and supported the assumption that the relationships of the series were not linear and could change over time. In this context, we determined the relationship between interest and freight rates by using time-varying causality analysis in this study. Since many factors are affecting both interest rate and freight rate, and their structures are exposed to too many shocks, the relationship between them may not be determined based on the whole sample. For this reason, we determined the periods in which the interest rate has affected freight rates, and whether the interest rate is a leading indicator by determining the relationship in different periods over time.

\section{Data}

The federal funds rate (The Federal Reserve System [FED], 2020) variable was chosen as a measure of the global interest rate, and the Baltic Dry Index (Bloomberg, 2020) was chosen as a measure of freight rates in the dry bulk market. The dataset used in the study consists of 302 observations monthly between January 1995 and February 2020. Descriptive statistics of the 
A. Açık, Ö. Okutucu, K. Ö. Efes \& S. Ö. Başer, “Analyzing The Impact of Interest Rate on Dry Bulk Freight Market With Time-Varying Causality Method"

dataset are presented in Table $1^{1}$. The BDI variable was used by taking the arithmetic mean of the daily values.

Table 1. Descriptive Statistics of Variables

\begin{tabular}{lcc}
\hline & BDI (Points) & Interest (\%) \\
\hline Mean & 2116.116 & 0.277682 \\
Median & 1437.020 & -0.215000 \\
Maximum & 10843.65 & 5.380000 \\
Minimum & 306.9048 & -3.810000 \\
Std. Dev. & 1885.094 & 2.099213 \\
Skewness & 2.414571 & 0.382707 \\
Kurtosis & 9.338078 & 2.080413 \\
Jarque-Bera & 798.9391 & 18.01303 \\
Probability & 0.000000 & 0.000123 \\
Observations & 302 & 302 \\
\hline
\end{tabular}

Source: Bloomberg (2020); FED (2020).

The movements of the variables in the considered period are presented in Figure 1. In this visual, no clear linear relationship can be seen between variables. This situation may be due to the nonlinearity of the relationship, not because there is no relationship between the variables. Additionally, since the BDI variable presents transportation costs as an indicator, it is also affected by factors such as oil prices, climatic events, cultural events, political events (Açık and Başer, 2018). This structure may be the main reason why a linear relationship cannot be determined.

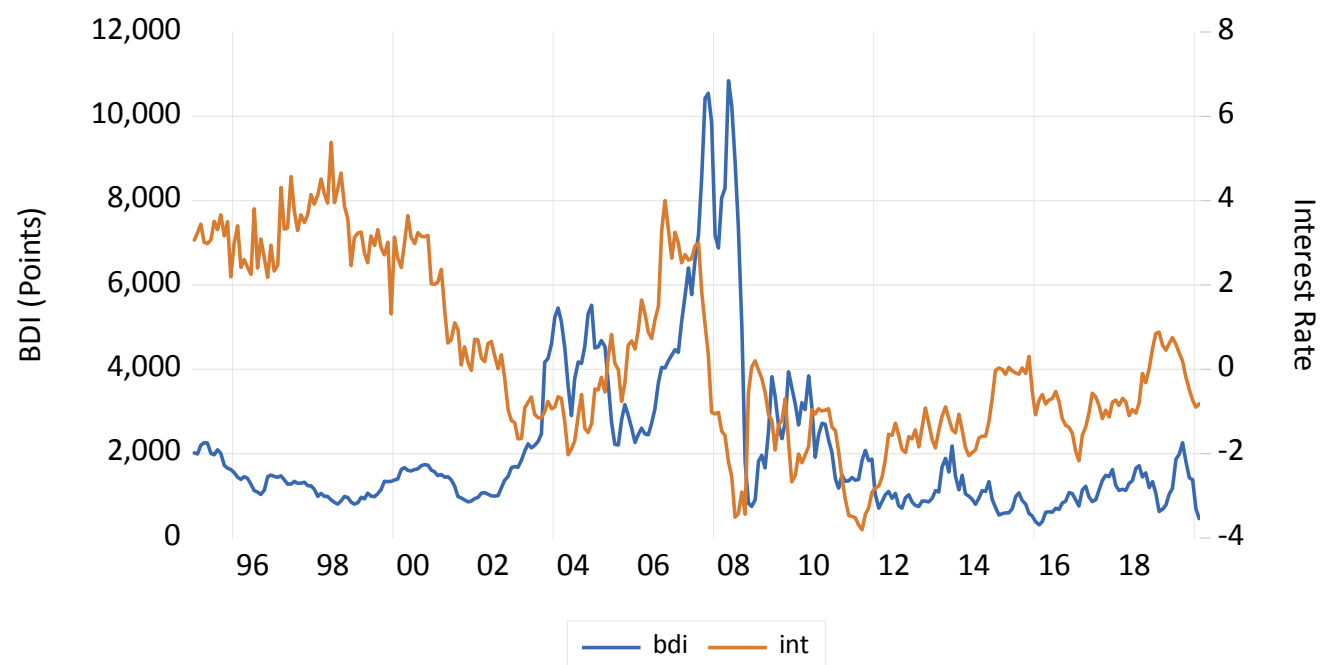

Figure 1. Graphical Display

Source: Bloomberg (2020); FED (2020).

\footnotetext{
${ }^{1}$ Ethics of research and publication were followed in this study, which does not require permission from the ethics committee and / or legal / special permission.
} 


\section{Results}

We first found it appropriate to apply the standard Granger causality test in the study. We thought this method would support us to choose the time-varying causality test as a method. While applying causality tests, the unit roots in the variables should be tested. In the standard causality test, the series should be stationary, while in the time-varying causality test, the maximum degree of integration should be determined. Accordingly, unit root tests of One break ADF test (Zivot and Andrews, 1992), One break LM test (Lee and Strazicich, 2013), Two break ADF test (Narayan and Popp, 2010) and Two break LM test (Lee and Strazicich, 2003) are applied to the series and results are presented in Table 2. Considering the breaks in the variables the null of unit root hypothesis is rejected for both variables in several tests. According to the results obtained, there are structural breaks in level and trend in 09.2003 and 07.2008 in BDI, and break in level in 11.2000 and break in level and trend in 07.2007 in interest rate.

Table 2. Unit Root Test with Structural Breaks

\begin{tabular}{|c|c|c|c|c|}
\hline Test Items & $\begin{array}{c}\text { Break in Level } \\
(\text { Mod A) } \\
\text { BDI } \\
\end{array}$ & $\begin{array}{c}\text { Break in Level and } \\
\text { Trend (Mod C) } \\
\text { BDI }\end{array}$ & $\begin{array}{c}\text { Break in Level } \\
(\operatorname{Mod} A) \\
\text { Interest } \\
\end{array}$ & $\begin{array}{c}\text { Break in Level and } \\
\text { Trend (Mod C) } \\
\text { Interest } \\
\end{array}$ \\
\hline \multicolumn{5}{|c|}{ One break ADF test (Zivot and Andrews, 1992) } \\
\hline ADF Stat & $-4.97^{* *}$ & $-5.57^{* * *}$ & -4.09 & -4.44 \\
\hline Break Date & 02.2007 & 07.2008 & 10.2000 & 12.2008 \\
\hline Fraction & 0.301 & 0.54 & 23 & 0.55 \\
\hline Lag & 9 & 9 & 0 & 0 \\
\hline \multicolumn{5}{|c|}{ One break LM test (Lee and Strazicich, 2013) } \\
\hline LM Stat & $-3.60^{* *}$ & $-4.93^{* *}$ & $-3.29^{*}$ & -3.90 \\
\hline Break Date & 09.2003 & 09.2003 & 11.2000 & 10.2008 \\
\hline Fraction & 0.34 & 0.34 & 0.23 & 0.55 \\
\hline Lag & 9 & 1 & 0 & 0 \\
\hline \multicolumn{5}{|c|}{ Two break ADF test (Narayan and Popp, 2010) } \\
\hline ADF Stat & $-6.04^{* * * *}$ & $-6.51^{* * *}$ & $-5.87^{* * *}$ & $-6.59^{* * *}$ \\
\hline Break Date & $01.2003,04.2010$ & $07.2002,07.2008$ & $10.2000,07.2007$ & $08.2002,07.2007$ \\
\hline Fraction & $0.32,0.60$ & $0.30,0.54$ & $0.23,0.50$ & $0.30,0.50$ \\
\hline Lag & 9 & 1 & 0 & 0 \\
\hline \multicolumn{5}{|c|}{ Two break LM test (Lee and Strazicich, 2003) } \\
\hline LM Stat & $-3.85^{* *}$ & $-5.52^{*}$ & $-3.58^{*}$ & -4.97 \\
\hline Break Date & $09.2003,06.2004$ & $08.2003,02.2016$ & $11.2000,11.2007$ & $11.2002,06.2009$ \\
\hline Fraction & $0.34,0.37$ & $0.34,0.84$ & $0.23,0.51$ & $0.31,0.57$ \\
\hline Lag & 9 & 9 & 0 & 0 \\
\hline
\end{tabular}

Note: Null of unit root is rejected $* 90 \%$, **95\%, ***99\%

The structural breaks detected in the variables are presented visually in Figure 2. Since September 2003 was the beginning of unprecedented demand for BDI, there was a positive break in both the level and trend. After July 2008, due to the beginning of the economic recession period and the surplus ship supply in the market, the freight rates crashed and a break in the level and trend occurred again. On the other hand, there was a break in level in interest rates in November 2000. Also, there was a decline in interest rates in July 2007 in response to the economic recession and this decline was reflected in the variable as a break in the level and trend. Such breaks in series make it difficult to identify significant econometric relationships, and therefore appropriate methods should be chosen. 


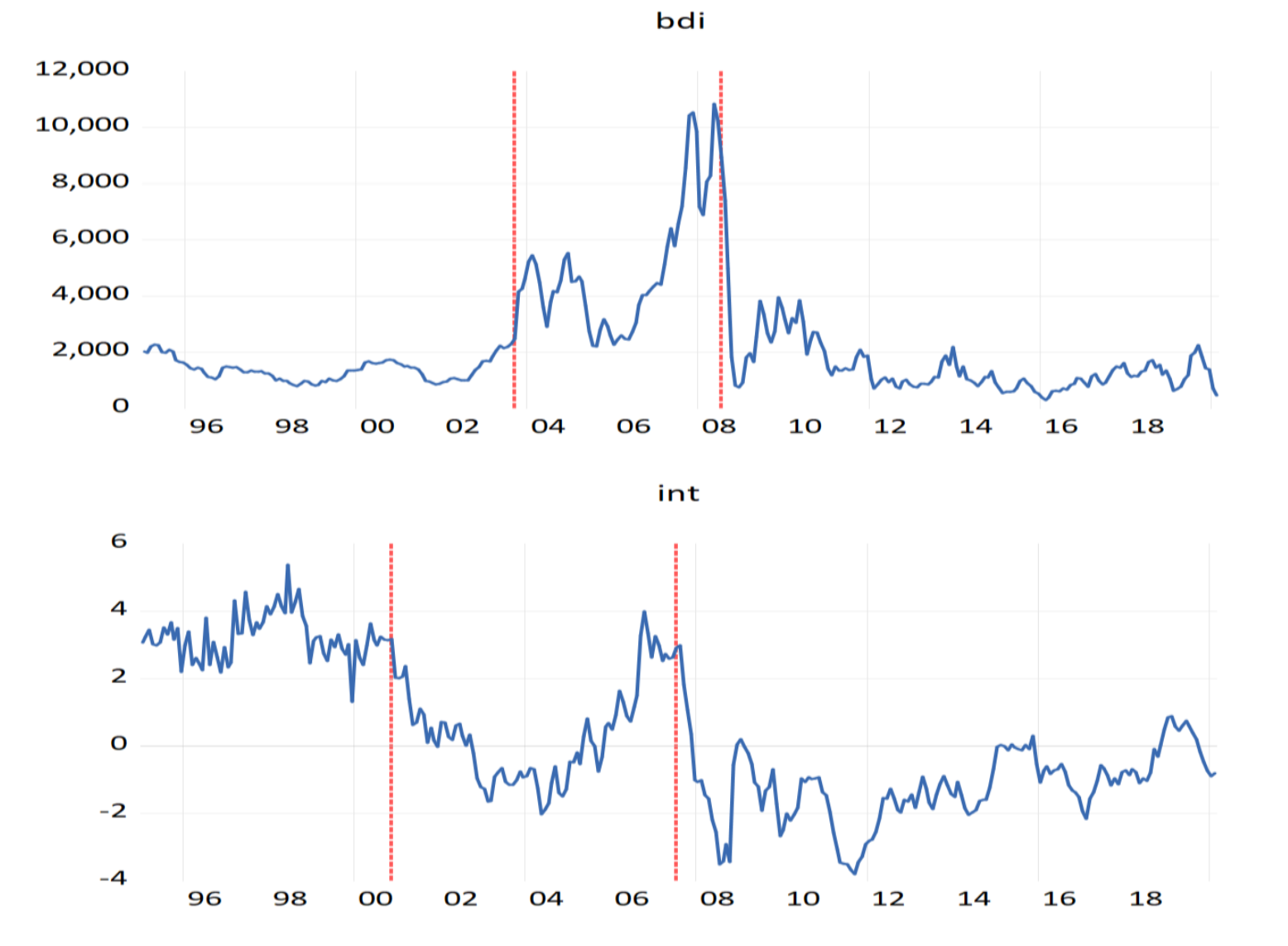

Figure 2. Structural Breaks in the Series

Since the variables are stationary at the level, they are suitable for standard Granger causality analysis. In the analysis applied between the variables, the lag length was determined based on the Akaike Information Criterion (AIC) value and was chosen as 2. According to the results of the analysis applied, the null of non-causality hypothesis could not be rejected for both cases. Not having a linear relationship may not mean that there is no relationship. It may be because the correct method has not been chosen. Considering the breaks in Figure 3, these breaks may lead to misleading econometric relationships.

Table 3. Granger Non-Causality Test Results

\begin{tabular}{lccc}
\hline Null Hypothesis & Chi-sq & Lag & Prob. \\
\hline Interest does not Granger cause BDI & 1.083676 & 2 & 0.58 \\
BDI does not Granger cause Interest & 3.961280 & 2 & 0.13 \\
\hline
\end{tabular}

We also tested whether the relationship between variables is linear or not. To test the linearity, we applied the BDS Independence test to the residuals of the VAR models in the linear causality analysis and presented the results in Table 4. As a result of the analysis for 6 dimensions, the linearity null hypothesis was rejected in both VAR models in all dimensions. This situation shows that the relationship between the variables is not linear. For these reasons, a causality test that changes over time may be more appropriate to determine the relationship. 
Table 4. Linearity Test Results

\begin{tabular}{ccccccc}
\hline \multicolumn{7}{c}{ VAR 1 } \\
\hline Dim. & BDS Statistic & Std. Error & z-Statistic & BDS Statistic & Std. Error & z-Statistic \\
\hline 2 & 0.015 & 0.005 & $2.823^{* * *}$ & 0.018 & 0.004 & $3.787^{* * * *}$ \\
3 & 0.034 & 0.008 & $3.980^{* * *}$ & 0.025 & 0.007 & $3.391^{* * *}$ \\
4 & 0.054 & 0.010 & $5.205^{* * *}$ & 0.030 & 0.009 & $3.393^{* * *}$ \\
5 & 0.067 & 0.010 & $6.208^{* * *}$ & 0.036 & 0.009 & $3.828^{* * *}$ \\
6 & 0.076 & 0.010 & $7.259^{* * *}$ & 0.037 & 0.009 & $4.125^{* * *}$ \\
\hline
\end{tabular}

Note: Null of linearity is rejected ${ }^{*} 90 \%,{ }^{* *} 95 \%,{ }^{* * *} 99 \%$

For time-varying causality analysis, the dmax value, which represents the maximum integration degree is selected as 0 , since both the variables are stationary considering the structural breaks. Following the determination of dmax value, the other initial values that should be selected before the analysis are the type of information criterion, the maximum number of lags, rolling window size and number of bootstrap replications. The number of bootstrap replications is selected as 1000 , the maximum number of lags is selected as 12 , and the window for rolling regression is selected as 50. AIC is used to select the optimum lag in the analysis. The maximum number of lags is 12 as the observations are monthly. If the rolling window is too small, it may not catch the causality. Conversely, if it is selected too large, it causes a loss of information. Therefore, the recommended value is usually 50. The critical value for determining the significance of the relationship is selected as 0.1, and GAUSS econometric software is used in the analysis. Following the determination of the initial values, the causal relationship between the real interest rate and BDI variables is examined unidirectional from the interest rate to the freight rate and the analysis result is presented in Figure 3. Probability value, critical value, and BDI value are presented in the figure. There is a significant relationship in periods when the probability value falls below the critical value. According to the results obtained, significant causal relationships are observed in 15 periods. These periods are 10 months between August 1999 - May 2000, 2 months between October 2002 - November 2002, 2 months between October 2003 - November 2003, 2 months between February 2004 - March 2004, 4 months between July 2004 - October 2004, 9 months between January 2005 - September 2005, 4 months between January 2006 - April 2006, 5 months between May 2008 - September 2008, 5 months between December 2008 - April 2009, 4 months between June 2010 - September 2010, 9 months between January 2011 - September 2011, 5 months between February 2015 - June 2015, 3 months between May 2017 - July 2017, 5 months between February 2019 - June 2019 and 3 months between December 2019 - February 2020. 


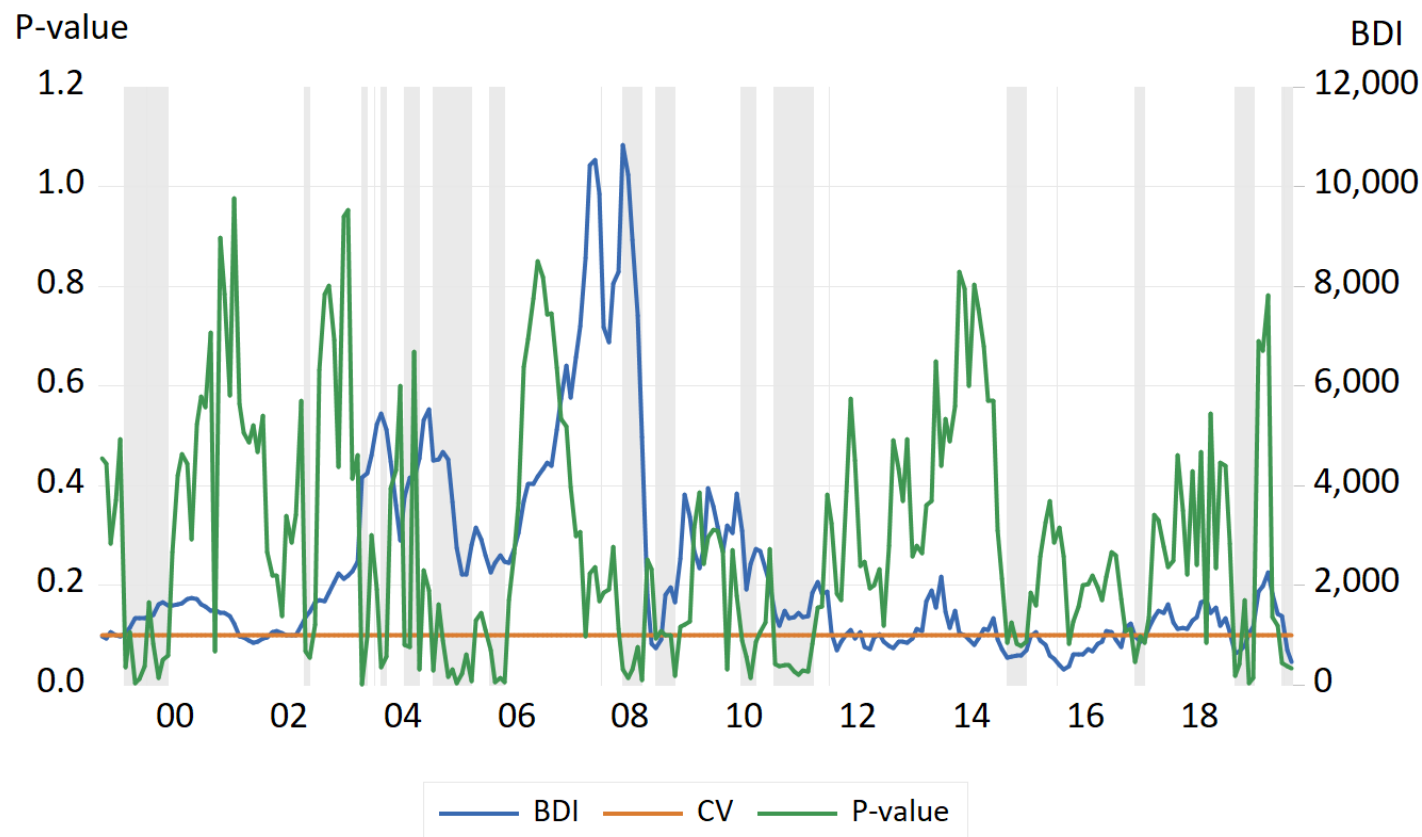

Figure 3. Causality Test Results

Since interest rates can act as a safety valve for the economy, their relationship with freight rates can be complicated. When the economy recovers, an increase in interest rates can be mentioned to calm the inflationary environment a little, so the amount of money in the market will decrease and individuals' tendency to save will increase. Here, economic activities may slow down as the demand for final products will decrease. This decrease could also negatively spread the maritime market, as shipping has a derived demand structure. In the results obtained in Figure 3, it was determined that significant causality relationships can be seen in both periods when BDI increases and decreases. According to our hypotheses, the decisions to increase the interest rates have a negative effect on freight rates as they increase the saving tendencies and decrease the consumption trends. On the other hand, as the decisions to decrease the interest rates increase the amount of money in the market, it increases consumption trends. It can be argued that interest rate decisions do not have the power to instantly influence consumers' consumption trends, but they still have a perceptual effect.

The direct impact of interest rates on the maritime market is more evident in asset-trading markets. Interest rates are the main determining factor when ship owners want to use credit to purchase a new ship as the rates directly affect the investment costs. Additionally, the monetary return he will earn by investing in the new ship should be more than he will get when he invested his capital in interest so that he invests. A similar situation occurs in the secondhand market and investors choose between interest income and commercial income. Finally, one can talk about the relationship between the demolition market and the interest rates. When the commercial return of the shipping business drops too low or the interest yields become more attractive, the shipowner can switch to other investment options by scrapping his assets. Or if the cost of purchasing a new ship is too expensive due to the high interest rates, the owner may decide to continue operating its old and obsolescence ship. In one of the rare empirical studies on this subject, it was found that the increase in interest rates decreased both the amount of new 
ship orders and the amount of ships sent for demolition (Aç1k et al., 2020). Also, as the increase in interest rates increases capital costs, a decrease in ship prices may be observed, since the demand for ships also decreases (Beenstock, 1985; Youngjae and Hyunsok, 2016). Both because the final cost of ownership increases and the opportunities for alternative returns increase.

The motivation of our research is that there is no empirical study examining the relationship between interest and freight rates in the literature. On the theoretical side, Beenstock (1985) has put forward that increasing interest rates will increase freight rates. However, the model presented by the researcher is a linear model. Our model, on the other hand, takes possible non-linear structures into account, and it has been determined that interest rates affect freight rates asymmetrically both when they rise and fall. In some periods when the economy was buoyant, the decrease in interest rates positively affected freight rates, and when the economy was stagnant, the increase in interest rates negatively affected freight rates in some periods. However, this interaction is invalid for the entire date range of the sample and it varies over time. The main reason for this is that many other variables affect freight rates such as world gross domestic product, industrial production, bunker price, secondhand value, fleet size, laid-up tonnage, and climatic, cultural, operational factors, etc. In this context, our study achieved accuracy in terms of the method chosen while examining the effect of the interest rate. On the other hand, different results have been obtained in empirical studies modeling interest rate and ship assets. In the study by Açık et al. (2020), freight positively affects the amount of ships ordered, while the interest rate negatively affects it. In the study by Youngjae and Hyunsok (2016), the effect of the interest rate on the value of the ship was determined to be negative. These two studies presented parallel findings. Increasing interest rates both increase capital costs and make alternative investment instruments more attractive. However, these studies were also applied on the basis of the whole sample. As the global economy in the world is dynamic and there are so many different variables affecting the maritime market, the dominant variables can change over time. For example, in the study by Açık and Ayaz (2018), it was determined that the effect of bunker prices, which is one of the most important items of costs, on freight rates vary according to time. In this respect, examining the studies on ship assets with a time-varying approach as we do, may increase the validity of the results. The main reason why this approach is required is that ship values and order quantities are mostly affected by freight rates, and in our research, it is determined that the effect of interest on freight varies with time.

\section{Conclusion}

Shipowners always encounter significant financial and business risks arising from freight rates, oil prices, foreign exchange rates, interest rates (Kavussanos and Visvikis, 2006). Since maritime transport is a sector that requires huge capital, reducing the risks arising from some uncertainty is important for sustainable commercial activities. In this regard, we analyzed the impact of interest rates on the freight rates in dry bulk shipping. To the best of the authors, there is no other empirical study in the literature examining the relationship between the freight market and interest rates. The Federal Funds Rate variable was chosen as a measure of the global interest rate, and the BDI was chosen as a measure of freight rates in the dry bulk market. 
Considering that there are many factors affecting freight rates, we also applied a timevarying causality analysis, following the standard causality analysis. Because the influence levels of the factors affecting freight rates may change over time and the effects of certain factors may come to the fore in some periods. In this respect, we could not get a significant result in our analysis based on the whole sample by standard causality. In the analysis results we made with a time-varying approach, we identified periods in which interest rates were significantly effective. These periods stand out as the periods in which freight rates are in an upward and downward trend. In this respect, the effect of interest rates on the amount of money in the market affects the demand for goods and is also reflected in the dry bulk freight market. These results empirically confirm that interest rates are an important leading indicator of carriers in the dry bulk market and contribute to reducing the risks arising from uncertainty for carriers.

For the maritime market, the global economic situation is the main determinant of the demand for transportation activities. In this respect, ship owners must follow global economic developments. The impact of the economic situation on freight rates has also been determined in several academic research (Başer and Açık, 2019). On the other hand, some macroeconomic tools shape the global economic situation. The most basic of these tools are interest rates. In this respect, according to the theoretical relationship between the economic situation and interest rates in the economic conjuncture, it is necessary for ship owners to estimate the state of the economic cycle and the possible interest step to be taken against it. Depending on the economic conditions, the effect of the interest rate on the economy and therefore on sea transport may be different. In this respect, we reveal that the indicators of ship-owners are not fixed, their effects change over time, and they need to be considered together with other important variables to make healthy assessments. Shipowners should assess the impact of interest rates relative to the position in the current economic cycle.

One limitation of the study is that the sub-indices that make up the BDI variable are not used sufficiently. At this point, further studies can examine this relationship using these subindices, which consequently provide market-specific results for the dry bulk freight market. It is also thought that the examination of this relationship in other maritime markets such as bunker, shipbuilding, demolition markets will yield interesting results.

\section{Researchers' Contribution Rate Statement}

The authors declare that they have contributed equally to the article.

\section{Conflict of Interest Statement}

There is no potential conflict of interest in this study. 


\section{References}

Açık, A. and Ayaz, İ. S. (2018). Time varying causality between cost and price: An empirical analysis on dry bulk shipping market. Journal of Business Research-Turk, 10(4), 136-147. https://doi.org/10.20491/isarder.2018.516

Açık, A. and Başer, S. Ö. (2018). An analytical study on the likely causes of the minor bubbles in the Baltic Dry Index. International Journal of Logistics Economics and Globalisation, 7(4), 353-365. https://doi.org/10.1504/IJLEG.2018.097478

Açık, A. and İnce, M. R. (2019). Income and asset value relationship: A nonlinear approach to Capesize shipping market. In S. Koc, S. Yilmaz Genc and V. H Benli (Eds.), Economic issues: Global and local perspectives (pp. 35-43). UK: Cambridge International Academics.

Açık, A., Kesiktaş, H. H. İ. and Başer, S. Ö. (2020). Role of interest rates on fleet capacity adjustment decisions of shipowners. Ekonomi, Politika \& Finans Araştırmalarl Dergisi, 5(1), 66-80. https://doi.org/10.30784/epfad.642061

Açık, A., Sağlam, B. B. and Tepe, R. (2019). Time-varying causality between exchange rate and container handling volume in Turkish ports. Transport \& Logistics: The International Journal, 19(46), 1-11. Retrieved from http://ulpad.fberg.tuke.sk/transportlogistics/

Agarwal, V. (2010). Macroeconomics: Theory and policy. India: Pearson.

Balcilar, M. and Ozdemir, Z. A. (2013a). Asymmetric and time- varying causality between inflation and inflation uncertainty in G-7 countries. Scottish Journal of Political Economy, 60(1), 1-42. https://doi.org/10.1111/sjpe.12000

Balcilar, M. and Ozdemir, Z. A. (2013b). The export-output growth nexus in Japan: A bootstrap rolling window approach. Empirical Economics, 44(2), 639-660. https://doi.org/10.1007/s00181-0120562-8

Bampinas, G. and Panagiotidis, T. (2015). On the relationship between oil and gold before and after financial crisis: Linear, nonlinear and time-varying causality testing. Studies in Nonlinear Dynamics \& Econometrics, 19(5), 657-668. https://doi.org/10.1515/snde-2014-0060

Başer, S. Ö. and Açık, A. (2019). The effects of global economic growth on dry bulk freight rates. Uluslararası Ticaret ve Ekonomi Araştırmalarl Dergisi, 3(1), 1-17. https://doi.org/10.30711/utead.507566

Beenstock, M. (1985). A theory of ship prices. Maritime Policy \& Management: The Flagship Journal of International Shipping and Port Research, 12(3), 215-225. https://doi.org/10.1080/03088838500000028

Bildirici, M. E. and Turkmen, C. (2015). Nonlinear causality between oil and precious metals. Resources Policy, 46, 202-211. https://doi.org/10.1016/j.resourpol.2015.09.002

Bloomberg. (2020). Baltic dry index [Dataset]. Retrieved from https://www.bloomberg.com/professional/

Branch, A. E. (2007). Elements of shipping. New York: Routledge.

Broock, W. A., Scheinkman, J. A., Dechert, W. D. and LeBaron, B. (1996). A test for independence based on the correlation dimension. Econometric Reviews, 15(3), 197-235. https://doi.org/10.1080/07474939608800353

Fabozzi, F. J, Modigliani, F. and Jones, F.J. (2014). Foundation of financial markets and institutions (4. Edition). USA: Pearson.

FED. (2019). Inflation and interest rates [Dataset]. Retrieved from https://fred.stlouisfed.org/series/FEDFUNDS

Geman, H. (2009). Risk management in commodity markets: From shipping to agriculturals and energy (Vol. 445). USA: John Wiley \& Sons.

Granger, C. W. (1969). Investigating causal relations by econometric models and cross-spectral method. Econometrica: Journal of the Econometric Society, 424-438. https://doi.org/10.2307/1912791 
A. Açık, Ö. Okutucu, K. Ö. Efes \& S. Ö. Başer, “Analyzing The Impact of Interest Rate on Dry Bulk Freight Market With Time-Varying Causality Method"

Inglesi-Lotz, R., Balcilar, M. and Gupta, R. (2014). Time-varying causality between research output and economic growth in US. Scientometrics, 100(1), 203-216. https://doi.org/10.1007/s11192-014$1257-\mathrm{z}$

Karakitsos, E. and Varnavides, L. (2014). Maritime economics: A macroeconomic approach. New York: Springer.

Kavussanos, M. G. and Visvikis, I. D. (2006). Shipping freight derivatives: A survey of recent evidence. Maritime Policy \& Management, 33(3), 233-255. https://doi.org/10.1080/03088830600783152

Langdana, F. K. (2009). Macroeconomic policy: Demystifying monetary and fiscal policy. USA: Springer.

Lawson, M. (2008). If not now, when? Three actions the G20 must take now to protect the World's poor from the economic crisis and build a new political and economic governance system. USA: Oxfam.

Lee, J. and Strazicich, M. C. (2003). Minimum lagrange multiplier unit root test with two structural breaks. The Review of Economics and Statistics, 85(4), 1082-1089. https://doi.org/10.1162/003465303772815961

Lee, J. and Strazicich, M. C. (2013). Minimum LM unit root test with one structural break. Economics Bulletin, 33(4), 2483-2492. Retrieved from http://www.accessecon.com/

Li, X. L., Balcilar, M., Gupta, R. and Chang, T. (2016). The causal relationship between economic policy uncertainty and stock returns in China and India: Evidence from a bootstrap rolling window approach. Emerging Markets Finance and Trade, 52(3), 674-689. https://doi.org/10.1080/1540496X.2014.998564

Ma, S. (2020). Economics of maritime business. New York: Routledge.

Narayan, P. K. and Popp, S. (2010). A new unit root test with two structural breaks in level and slope at unknown time. Journal of Applied Statistics, 37(9), 1425-1438. https://doi.org/ $10.1080 / 02664760903039883$

Poulakidas, A. and Joutz, F. (2009). Exploring the link between oil prices and tanker rates. Maritime Policy \& Management, 36(3), 215-233. https://doi.org/10.1080/03088830902861094

Shen, C. W. and Chou, C. C. (2015, August). Temporal causality between dry bulk freight and crude oil price. Paper presented at the International Association of Maritime Economists (IAME) conference, Kuala Lumpur, Malaysia.

Strandenes, S. P. (1984). Price determination in the time charter and second hand markets (Center for Applied Research, Norwegian School of Economics and Business Administration, Working Paper MU, 6). Retrieved from https://www.econbiz.de/

Şahin, B., Gürgen, S., Ünver, B. and Altin, I. (2018). Forecasting the Baltic Dry Index by using an artificial neural network approach. Turkish Journal of Electrical Engineering \& Computer Sciences, 26(3), 1673-1684. Retrieved from https://dergipark.org.tr/tr/pub/tbtkelektrik

UNCTAD. (2018). Review of maritime transport 2018. Retrieved from https://unctad.org/system/files/official-document/rmt2018_en.pdf

United Nations. (2009). World economic situation and prospects 2009 (World economic and social survey supplement). Retrieved from https:/www.un.org/es/file/71089/download?toke $\mathrm{n}=\mathrm{TbJO} 7 \mathrm{hmb}$

Vermeulen, K. J. (2010). Framing a canvas for shipping strategy. In C. Grammenos (Ed.), The handbook of maritime economics and business (pp. 851-888). London: Lloyd's List.

Yin, J., M. Luo and L. Fan. (2017). Dynamics and interactions between spot and forward freights in the dry bulk shipping market. Maritime Policy \& Management, 44(2), 271-288. https://doi.org/10.1080/03088839.2016.1253884

Youngjae, C. and Hyunsok, K. (2016). The spillover from asset determinants to ship price. The Korea Port Economic Association, 32(2), 59-71. Retrieved from https://www.koreascience.or.kr/ 
Ekonomi, Politika \& Finans Araştırmaları Dergisi, 2021, 6(2): 403-417

Journal of Research in Economics, Politics \& Finance, 2021, 6(2): 403-417

Zannetos, Z. S. (1966). The theory of oil tankship rates. USA: Massachusetts Institute of Technology.

Zivot, E. and Andrews, D. W. K. (2002). Further evidence on the great crash, the oil-price shock, and the unit-root hypothesis. Journal of Business \& Economic Statistics, 20(1), 25-44. https://doi.org/ $10.2307 / 1391541$ 